OPEN ACCESS

Edited by:

Toshi Nagata,

The University of Tokyo, Japan

Reviewed by:

Marta Plavsic,

Rudjer Boskovic Institute, Croatia

Hiroshi Ogawa

The University of Tokyo, Japan

*Correspondence:

Jordan Toullec

brivaela.moriceau@univ-brest.fr

Specialty section:

This article was submitted to Marine Biogeochemistry, a section of the journal Frontiers in Marine Science

Received: 08 September 2017 Accepted: 12 March 2018

Published: 28 March 2018

Citation:

Toullec J and Moriceau B (2018) Transparent Exopolymeric Particles (TEP) Selectively Increase Biogenic Silica Dissolution From Fossil Diatoms as Compared to Fresh Diatoms.

Front. Mar. Sci. 5:102.

doi: 10.3389/fmars.2018.00102

\section{Transparent Exopolymeric Particles (TEP) Selectively Increase Biogenic Silica Dissolution From Fossil Diatoms as Compared to Fresh Diatoms}

\author{
Jordan Toullec* and Brivaëla Moriceau \\ Laboratoire des Sciences de l'Environnement Marin, UMR 6539 CNRS, Institut Universitaire Européen de la Mer (IUEM), \\ Université de Bretagne Occidentale (UBO), Plouzané, France
}

Diatom production is mainly supported by the dissolution of biogenic silica $\left(\mathrm{bSiO}_{2}\right)$ within the first $200 \mathrm{~m}$ of the water column. The upper oceanic layer is enriched in dissolved and/or colloidal organic matter, such as exopolymeric polysaccharides (EPS) and transparent exopolymeric particles (TEP) excreted by phytoplankton in large amounts, especially at the end of a bloom. In this study we explored for the first time the direct influence of TEP-enriched diatom excretions on $\mathrm{bSiO}_{2}$ dissolution. Twelve dissolution experiments on fresh and fossil diatom frustules were carried out on seawater containing different concentrations of TEP extracted from diatom cultures. Fresh diatom frustules were cleaned from the organic matter by low ash temperature, and fossil diatoms were made from diatomite powder. Results confirm that newly formed $\mathrm{bSiO}_{2}$ dissolved at a faster rate than fossil diatoms due to a lower aluminum (Al) content. Diatom excretions have no effect on the dissolution of the newly formed $\mathrm{bSiO}_{2}$ from Chaetoceros muelleri. Reversely, the diatomite specific dissolution rate constant and solubility of the $\mathrm{bSiO}_{2}$ were positively correlated to TEP concentrations, suggesting that diatom excretion may provide an alternative source of dSi when limitations arise.

Keywords: exopolysaccharide, diatom excretion, diatomite, Chaetoceros muelleri, biogenic silica, $\mathrm{bSiO}_{2}$ dissolution, TEP

\section{INTRODUCTION}

The terrestrial lithosphere is composed of $27 \%$ (by weight) silicon. As a nutrient and required element of various marine organisms, silicon has an important part in biogeochemical processes. At a global scale, silica and carbon cycles are coupled by silicifying organisms via photosynthesis. In the marine realm, diatoms (Bacillariophyceae), unicellular phytoplankton with an absolute requirement for silicon to build their frustules composed of amorphous polymerised silica $\left(\mathrm{bSiO}_{2}\right)$, are key silicifying organisms that play an important role in the marine biogeochemical cycling of carbon. They are responsible for nearly $40 \%$ of the global primary production (Nelson et al., 1995; Rousseaux and Gregg, 2013). This contribution to the carbon cycle varies greatly according to the oceanic region and period of the year. For example, the contribution of diatoms to the global primary production varies between $25 \%$ in oligotrophic conditions (Brzezinski et al., 2011) to $75 \%$ in eutrophic ocean areas (Nelson et al., 1995). Diatoms are also a major component of the marine 
biological carbon pump (Smetacek, 1999; Jin et al., 2006; Sanders et al., 2014) and are the base of some of the most successful food webs (Irigoien et al., 2002).

Approximately $50-60 \%$ of diatomaceous biogenic silica $\left(\mathrm{bSiO}_{2}\right)$ produced in the euphotic layer is remineralized within the first 100-200 $\mathrm{m}$ of the water column (Tréguer et al., 1995; Van Cappellen et al., 2002; Passow et al., 2003). This process of $\mathrm{bSiO}_{2}$ dissolution provides diatoms with their main source of dissolved silicon, in the form of dissolved silica ( $\mathrm{dSi}$ ), which in turn, supports diatom growth for $50 \%$ of the global silicon budget established by Tréguer and De La Rocha (2013). Silica dissolution in the surface ocean of the northwest African upwelling regions was sufficient to supply all silicic acid taken up by phytoplankton (Nelson and Goering, 1977; Nelson et al., 1981). As such, biogenic silica dissolution is an important process that needs to be better understood and quantified, with particular emphasis on its variability in different environmental contexts. The dissolution of $\mathrm{bSiO}_{2}$ depends on abiotic factors, such as specific surface area, temperature, salinity, pressure, $\mathrm{pH}$, and aluminum concentration (Van Cappellen et al., 2002; Loucaides et al., 2012). Less studied, biotic factors also influence $\mathrm{bSiO}_{2}$ dissolution. Diatom frustules are surrounded by an organic coating that needs to be removed by prokaryotes before dissolution of the frustule can begin (Bidle and Azam, 2001). In addition, biogenic silica dissolution depends on nutritive growth conditions of the diatoms (Boutorh et al., 2016). The process of silicification is known to be influenced by stressful conditions, such as nutrient limitation (Boyle, 1998; Takeda, 1998; Lasbleiz et al., 2014) and/or the presence of grazers (Pondaven et al., 2007).

Polysaccharides (EPS) are abundant in the surface waters of the global ocean and are typically found in the nutrient limited conditions at the end of a phytoplankton bloom (Passow, 2002a; Claquin et al., 2008). EPS are mainly secreted by diatoms and bacteria, though other types of phytoplankton can also contribute (Passow, 2002a). EPS are sticky and easily aggregate to form transparent exopolymeric particles (TEP), an essential trigger for mass flocculation during a phytoplankton bloom (Mari and Kiørboe, 1996; Passow, 2002b). Their size ranges from colloidal $(1 \mathrm{kDa}$ ) to $100 \mu \mathrm{m}$, and they can reach abundances of 40,000 particles $\mathrm{mL}^{-1}$ or $11 \mathrm{mg} \mathrm{X}_{\mathrm{eq}} \mathrm{L}^{-1}$ (Mari and Burd, 1998; Passow, 2002 b), contributing to $\sim 10-25 \%$ of the DOM pool in surface waters (Passow, 2002b; Thornton, 2014). In such conditions, when turbulence favors collisions, TEP promote aggregation with cells included in the TEP matrix. In diatom aggregates $\mathrm{bSiO}_{2}$ dissolution is slower than in the surrounding seawater (Moriceau et al., 2007b). The decrease of $\mathrm{bSiO}_{2}$ dissolution rates inside aggregates have, for the first time, been attributed to the longer viability of aggregated diatoms (Garvey et al., 2007) and to higher $\mathrm{dSi}$ concentrations in the pore water due to adsorption processes (Moriceau et al., 2007a, 2014). Another hypothesis is that the TEP matrix also protects the $\mathrm{bSiO}_{2}$ against dissolution. EPS inhibits the dissolution of Al-enriched lithogenic silica $\left(\mathrm{ISiO}_{2}\right)$, such as feldspar, kaolinite, and quartz (Welch and Ullman, 1993, 1996; Ullman et al., 1996). Conversely, in some cases, bacterial byproducts such as organic acids promote $\mathrm{ISiO}_{2}$ dissolution (Welch and Ullman, 1993, 1996; Vandevivere et al., 1994) which is much more resistant to dissolution than $\mathrm{bSiO}_{2}$. If this is true, it can be of great importance for the dissolution occurring both in the surface layer and in sediments. Similar to what can be found in the surface layer, TEP are sometimes concentrated at the surface of sediments due to massive sedimentation of aggregates or from the direct activity of benthic organisms (Wotton, 2004). Despite their abundance in the surface waters and sediments, two important components of the water column for $\mathrm{bSiO}_{2}$ dissolution processes, no study has measured the influence of TEP on the dissolution of diatomaceous $\mathrm{bSiO}_{2}$. In this context, the goal of the present study is to understand the influence of TEP concentrations on the dissolution of freshly cleaned and fossil diatom $\mathrm{bSiO}_{2}$.

\section{MATERIALS AND METHODS}

In order to understand how diatom excretion products influence $\mathrm{bSiO}_{2}$ dissolution, we conducted two sets of dissolution experiments under batch conditions. Each set of conditions consisted of amorphous silica dissolution experiments in seawater containing different concentrations of TEP-enriched diatom excretion products. The dissolution of two different types of silica: Fossil diatoms and fresh diatoms, were evaluated. For the first set of experiments we used diatomite (fossil diatoms), for the second set of experiments we used dead diatoms Chaetoceros muelleri cleaned from their organic coating.

\section{Samples Preparation}

$\mathrm{bSiO}_{2}$ from diatomite (fossil diatoms) exists as a commercial product, a fine powder that is a chalk-like, soft, friable, earthy, very-fine grained, and siliceous sedimentary rock, usually light in color. The measured Si:Al ratio (moles:moles) of the diatomite was 4.8. Fresh $\mathrm{bSiO}_{2}$ from diatoms came from a culture of C. muelleri (strain CCAP 1010-3) provided by Ifremer's Argenton experimental station (Argenton, France). Fresh algae cultures were grown using a Conway culture medium (Salinity $=35.2$ PSU), at $20^{\circ} \mathrm{C}$ with $100 \mu \mathrm{mol} \mathrm{m}^{-2} \mathrm{~s}^{-1}$ light on a $24: 0 \mathrm{~h}$ light:dark cycle. The final cell concentration was $3.9 \times 10^{6}$ cells $\mathrm{mL}^{-1}$ after we isolated diatom byproducts and $\mathrm{bSiO}_{2}$. Ten liters of this culture solution was centrifuged at $3,000 \mathrm{~g}$ for $10 \mathrm{~min}$ at $15^{\circ} \mathrm{C}$ (Thermo Scientific Heraeus ${ }^{\circledR}$ Multifuge ${ }^{\circledR}$ 3SR Plus). Following protocols commonly used for $\mathrm{bSiO}_{2}$ dissolution experiments, the pellets were rinsed three times with milliQ water to remove salts and residual $\mathrm{dSi}$, centrifuged, and then frozen at $-20^{\circ} \mathrm{C}$ prior lyophilisation during $72 \mathrm{~h}$. Fresh diatom $\mathrm{bSiO}_{2}$ was cleaned from the external organic membrane by low ash combustion in a plasma oven (Gala intrumente ${ }^{\circledR}$ Plasma-ACE 5 ; Dixit and Van Cappellen, 2003; Loucaides et al., 2008). Despite the $10 \mathrm{~L}$ of highly concentrated diatom culture, we were only able to collect $254 \mu \mathrm{mol}$ of $\mathrm{bSiO}_{2}$.

\section{TEP Gradient}

In order to extract byproducts from diatoms, another $10 \mathrm{~L}$ of C. muelleri culture at the stationary phase was kept in the dark for several days at $20^{\circ} \mathrm{C}$. Diatom by-products were isolated from the diatoms by filtration through a $1 \mu \mathrm{m}$ polycarbonate filter (C. muelleri, single cell size range from 4 to $6 \mu \mathrm{m}$ ). The resulting seawater was strongly enriched in TEP (TEP > $0.4 \mu \mathrm{m}: 4.1 \pm$ 
$1 \mathrm{mg} \mathrm{X}_{\mathrm{eq}} \mathrm{L}^{-1}$ ) and contained no diatoms. Five solutions were prepared from different mixtures of the TEP-enriched medium and natural seawater from the Bay of Brest, pre-filtered using a $0.22 \mu \mathrm{m}$ polycarbonate filter (Salinity $=33.5 \mathrm{PSU}$, $\left[\mathrm{SiOH}_{4}\right]$ $=8 \mu \mathrm{mol} \mathrm{L}-1,\left[\mathrm{NO}_{3}\right]=18.35 \mu \mathrm{mol} \mathrm{L}-1,\left[\mathrm{NO}_{2}\right]=0.20 \mu \mathrm{mol}$ $\left.\mathrm{L}^{-1},\left[\mathrm{PO}_{4}\right]=0.45 \mu \mathrm{mol} \mathrm{L} \mathrm{L}^{-1}\right)$. We expected an increasing TEP concentration range from the mixing of the two mother solutions. TEP-enriched to seawater vol:vol ratios were 0 for D1, 0.25 for D2, 0.5 for D3, 0.75 for D4, and 1 for D5. The salinity change in our medium from D1 to D5 did not exceed 1.7 PSU.

\section{Batch Preparation}

Nine $500 \mathrm{~mL}$ polycarbonate batches were used in the diatomite experiment: D1, D2, D3, D4, and D5, with D1 and D5 in triplicate. Each batch contained $15 \mathrm{mg}$ of diatomite. For the second set of experiments with freshly cleaned diatoms, due to the low amount of $\mathrm{bSiO}_{2}$ collected from the $10 \mathrm{~L}$ of $C$. muelleri culture, only three polycarbonate batches of $125 \mathrm{~mL}$ were prepared using three dilutions: D1, D2, and D5. The initial $\mathrm{bSiO}_{2}$ concentrations were $\sim 500 \mu \mathrm{M}$ in all batches.

\section{Dissolution Experiment}

All batches were incubated in the dark, at $16^{\circ} \mathrm{C}$, during 30 days on a shaking table for continuous agitation, allowing for a better homogenization of the particles in the batch. Batch cultures were kept ajar during the 30 days, in order to preserve gases exchanges, which have been proven to limit $\mathrm{CO}_{2}$ surplus and $\mathrm{pH}$ changes (Suroy et al., 2014, 2015; Boutorh et al., 2016). The dSi concentrations were measured on a daily basis for 4 days, and every second day until the end of the experiment.

\section{TEP Sampling and Measurement}

The method of Passow and Alldredge (1995) was used for TEP measurements. Three to five replicates for each solution were sampled at the beginning of the experiment. Under low-pressure conditions, $15 \mathrm{ml}$ was filtered onto $0.4 \mu \mathrm{m}$ polycarbonate filters (according to Passow and Alldredge, 1995) and stained with 0.5 $\mathrm{mL}$ of a $0.02 \%$ aqueous solution of pre-filtered Alcian blue in $0.06 \%$ acetic acid ( $\mathrm{pH} 2.5$ ). Filters were kept at $-20^{\circ} \mathrm{C}$ until analysis. Filters were soaked for $2 \mathrm{~h}$ in $6 \mathrm{~mL}$ of $80 \% \mathrm{H} 2 \mathrm{SO} 4$ under agitation. The absorption measured at $787 \mathrm{~nm}$ in a $1 \mathrm{~cm}$ cuvette was converted into grams of Gum Xanthan equivalent per liter ( $\mathrm{g} \mathrm{Xeq}^{-1}$ ) using a calibration curve done for our working solution of Alcian blue.

\section{Dissolved and Particulate Biogenic Silica Measurements}

Samples were filtered through $0.4 \mu \mathrm{m}$ polycarbonates Millipore filters. Filtrates were preserved at $4^{\circ} \mathrm{C}$ in $15 \mathrm{~mL}$ polycarbonate falcon tubes prior to analysis for dSi. Millipore filters were dried during $24 \mathrm{~h}$ at $55^{\circ} \mathrm{C}$ inside Petri box, and then kept at room temperature before digestion and analysis for $\mathrm{bSiO}_{2}$. Filters were digested in $8 \mathrm{~mL}$ of $\mathrm{NaOH}(0.2 \mathrm{M})$ during $4 \mathrm{~h}$ at $90^{\circ} \mathrm{C}$ under constant agitation. Digestion was stopped by cooling the solution and neutralized with $2 \mathrm{~mL}$ of chloride acid (1 M). All samples were then centrifuged at $3,000 \mathrm{~g}$ at $20^{\circ} \mathrm{C}$ during $5 \mathrm{~min}$.
Supernatants containing the dissolved silica $(\mathrm{dSi})$, were analyzed by AutoAnalyzer.

\section{Chemistry Analysis}

Silicic Acid ( $\mathrm{dSi}$ ) was analyzed using the automated colorimetric method on a Technicon AutoAnalyzer according to the protocol established by Tréguer and Le Corre (1975) and optimized by Aminot and Kérouel (2007). Samples are guided by a pump in a continuous flux, through a circuit in which dissolved silica $(\mathrm{dSi})$ reacts with ammonium molybdate, at low $\mathrm{pH}$, to produce $\beta$-silicomolybdique acid. This acid is then reduced by methylamino-4-phenol sulfite and a sodium sulfite solution, resulting in a final product absorbing at $810 \mathrm{~nm}$.

\section{Kinetic Calculation}

In the present study, $\mathrm{bSiO}_{2}$ dissolution was monitored by following the $\mathrm{dSi}$ concentration with time (Equation 1) as described as:

$$
d S i_{(t)}=d S i_{(e)} \cdot\left(1-e^{-K t}\right)
$$

The specific dissolution rate constant $\left(\mathrm{K}, \mathrm{d}^{-1}\right)$ was determined using the slope at the origin of the plot of the $\ln \left(\frac{d S i_{(e)}-\left(d S i_{(t)}-d S i_{(0)}\right)}{d S i_{(e)}}\right)$ vs. time (Equation 2), which corresponds to exponential dissolution phases (Kamatani and Riley, 1979; Greenwood et al., 2001; Truesdale et al., 2005; Roubeix et al., 2008).

$$
\frac{d\left[\ln \left(\frac{d S i_{(e)}-\left(d S i_{(t)}-d S i_{(0)}\right)}{d S i_{(e)}}\right)\right]}{d t}=-K
$$

Where $d S i_{(t)}$ is $d S i$ concentration $\left(\mu \mathrm{mol} \mathrm{L}^{-1}\right)$ measured at time $t$ (day), $d S i_{(0)}$ is initial $d S i$ concentration $\left(\mu \mathrm{mol} \mathrm{L} \mathrm{L}^{-1}\right)$, and $d S i_{(e)}$

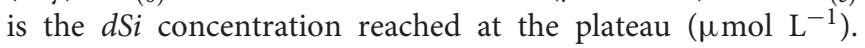
For diatomite dissolution experiments, $d S i_{(e)}$ corresponds to the apparent solubility of the $\mathrm{bSiO}_{2}$, because the $500 \mu \mathrm{M} \mathrm{bSiO}$ initially added was never totally dissolved in the dissolution batch. For the $\mathrm{bSiO}_{2}$ dissolution experiments using the freshly cleaned diatoms, $d S i_{(e)}$ is equal to the initial $\mathrm{bSiO}_{2}$ concentration $(\mu \mathrm{mol} \mathrm{L}-1)$.

\section{Statistical Analysis}

Correlations between the kinetic parameters of $\mathrm{bSiO}_{2}$ (specific dissolution rate constant and apparent solubility of the $\mathrm{bSiO}_{2}$ ) and TEP concentrations are tested with non-parametric Spearman rank correlation, using $\mathrm{R}$ software with function: cor.test() method = "Spearman."

\section{RESULTS}

TEP concentrations $(>0.4 \mu \mathrm{m})$ increased from D1 to D5, with values from $2.4 \pm 0.2$ to $4.7 \pm 0.2 \mathrm{mg} \mathrm{X}_{\mathrm{eq}} \mathrm{L}^{-1}$ (Table 1).

The dissolution of $\mathrm{bSiO}_{2}$ was clearly visible in the two sets of experiments from the progressive increase of the dSi concentrations with time (Figures 1, 2). This increase was steeper for freshly cleaned diatoms than for fossil diatoms. In the fresh $\mathrm{bSiO}_{2}$ dissolution experiments, a small plateau of $\mathrm{dSi}$ 


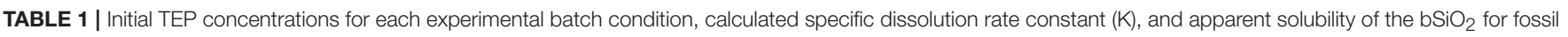
diatoms cleaned diatoms.

\begin{tabular}{|c|c|c|c|c|c|}
\hline Batches & $\begin{array}{l}\text { TEP > } 0.4 \mu \mathrm{m} \\
\left(\mathrm{mg} \mathrm{X}_{\mathrm{eq}} \mathrm{L}^{-1}\right)\end{array}$ & $\begin{array}{l}\text { TEP > } 0.2 \mu \mathrm{m} \\
\left(\mathrm{mg} \mathrm{X}_{\mathrm{eq}} \mathrm{L}^{-1}\right)\end{array}$ & $\mathrm{bSiO}_{2}$ & $\begin{array}{l}\text { Specific dissolution } \\
\text { rate constant }\left(d^{-1}\right)\end{array}$ & $\begin{array}{l}\text { Apparent solubity of } \\
\mathrm{bSiO}_{2}\left(\mu \mathrm{mol} \mathrm{L}^{-1}\right)\end{array}$ \\
\hline \multirow[t]{2}{*}{ D1 } & $2.4( \pm 0.2)$ & $5.7( \pm 0.8)$ & Cleaned diatoms & 0.3 & - \\
\hline & & & Fossil diatoms & $0.17( \pm 0.01)$ & $62( \pm 6)$ \\
\hline \multirow[t]{2}{*}{ D2 } & $2.7( \pm 0.2)$ & 7.0 & Cleaned diatoms & 0.3 & - \\
\hline & & & Fossil diatoms & 0.19 & 87 \\
\hline D3 & $3.7( \pm 0.5)$ & 7.3 & Fossil diatoms & 0.19 & 1,02 \\
\hline D4 & $4.7( \pm 0.2)$ & 9.1 & Fossil diatoms & 0.29 & 127 \\
\hline \multirow[t]{2}{*}{ D5 } & $4.1( \pm 1.6)$ & $7.7( \pm 0.5)$ & Cleaned diatoms & 0.18 & - \\
\hline & & & Fossil diatoms & $0.24( \pm 0.07)$ & $163( \pm 18)$ \\
\hline
\end{tabular}

concentration was observed when all the $\mathrm{bSiO}_{2}$ initially added to the batch was dissolved. In the dissolution batch containing fossil diatoms, the $\mathrm{dSi}$ concentrations stabilized after $120 \mathrm{~h}$ when they reached a plateau (Figure 1) equivalent to the apparent solubility of the $\mathrm{bSiO}_{2}$. The apparent solubility of the $\mathrm{bSiO}_{2}$ also increased from $\mathrm{D} 1$ to $\mathrm{D} 5$, with values from $62 \mu \mathrm{M}$ in $\mathrm{D} 1,87 \mu \mathrm{M}$ in $\mathrm{D} 2$, $102 \mu \mathrm{M}$ in D3, $127 \mu \mathrm{M}$ in D4, and $163 \mu \mathrm{M}$ in D5 (Table 1, Figure 1).

Diatomite specific dissolution rate constants varied from 0.16 to $0.35 \mathrm{~d}^{-1}$ from D1 to D5 (Table 1). The specific dissolution rate constants of the freshly cleaned diatoms (C. muelleri) varied from 0.18 to $0.31 \mathrm{~d}^{-1}$ (Table 1). Our constants are close to the average specific dissolution rate constants of $0.15 \pm 0.15$ $\mathrm{d}^{-1}$ given for cleaned frustules by Roubeix et al. (2008). For diatomite dissolution, a significant correlation was revealed between specific dissolution rate constants and $>0.4 \mu \mathrm{m}$ TEP concentrations (Figure 3; Spearman correlation $=0.7^{*}, p$-value $=0.022, N=9$ experiments). Similarly, a significant correlation was found between apparent solubility of the $\mathrm{bSiO}_{2}$ and $>0.4$ $\mu \mathrm{m}$ TEP concentrations (Figure 3; Spearman correlation = $0.867^{* *}, p$-value $=0.002, N=9$ experiments). By contrast, no correlation between specific dissolution rate constants and TEP concentrations was observed for the freshly cleaned diatoms (Figure 3).

\section{DISCUSSION}

Specific dissolution rate constant and apparent solubility of $\mathrm{bSiO}_{2}$ were correlated with TEP concentration. We were able to create a concentration gradient of TEP in the dissolution batches from the different dilutions between the TEP-enriched medium and the natural filtered seawater. TEP concentrations in D1 that contained only $0.22 \mu \mathrm{m}$ filtered natural seawater were negligible $\left(2.4 \pm 0.2 \mathrm{mg} \mathrm{X}_{\mathrm{eq}} \mathrm{L}^{-1}\right)$. TEP are sticky particles (Passow, 2002b; Mari et al., 2017) that aggregate easily in solution, especially under continuous agitation. The different solutions also contained $<0.2 \mu \mathrm{m}$ TEP. With this fraction, TEP concentrations were on average twice as high (Table 1). Our measurement suggests that in the filtered seawater, small TEP particles (lower than $0.2 \mu \mathrm{m}$ ) have aggregated into TEP particles with diameters larger than $0.4 \mu \mathrm{m}$. As most of the studies are measuring TEP $>0.4 \mu \mathrm{m}$, we decided to refer only to these measurements when talking about TEP concentrations in the following discussion. Finally, we obtained TEP concentrations ranging from 2 to $6 \mathrm{mg} \mathrm{X}_{\mathrm{eq}} \mathrm{L}^{-1}$ that reflect what can be seen in situ according to Passow and Alldredge (1995), who gave natural values in a range of $0.02-11 \mathrm{mg} \mathrm{X}_{\mathrm{eq}} \mathrm{L}^{-1}$.

Dissolved silica $(\mathrm{dSi})$ concentrations increased with time following the pattern generally seen in similar dissolution experiments. We observed some variability in the dissolution pattern with $\mathrm{dSi}$ concentrations data higher or lower than expected from Equation (1). At such high TEP concentrations, as seen in situ with high concentrations of phytoplankton, the seawater viscosity is influenced, affecting the swimming behavior of the zooplankton (Seuront, 2006). High viscosity decreases the diffusion of the dSi (Eyring, 1936), which may explain the variability of $\mathrm{dSi}$ concentrations as compared to the normal pattern, despite the mixing of the batches.

The $\mathrm{bSiO}_{2}$ from cleaned frustules dissolved on average five times faster than $\mathrm{bSiO}_{2}$ still surrounded by an external membrane (0.03 vs. $0.15 \mathrm{~d}^{-1}$, Roubeix et al., 2008). In our study, we measured similar dissolution rates for the cleaned $\mathrm{bSiO}_{2}$ from fresh C. muelleri with an average specific dissolution rate constant of $0.22 \mathrm{~d}^{-1}$. bSiO 2 dissolved at $0.3 \mathrm{~d}^{-1}$ in the two batches containing less TEP, while in the third dissolution experiment the rate constant was $0.18 \mathrm{~d}^{-1}$. One experiment is not sufficient to clearly demonstrate a potential influence of diatom excretion on $\mathrm{bSiO}_{2}$ dissolution. However, a similar trend was observed in the study by Roubeix et al. (2008), in which they suggested a possible "blockage effect," due to the physical coating of the $\mathrm{bSiO}_{2}$ surface that may slow down access to the surface by water molecules.

At similar TEP concentrations, $\mathrm{bSiO}_{2}$ from freshly cleaned frustules dissolved slightly faster than $\mathrm{bSiO}_{2}$ from diatomite $(0.3$ vs. $0.18 \mathrm{~d}^{-1}$, Table 1$)$. During its stay in the sediment, "reverse weathering" processes such as Al-Si substitutions progressively decreased the reactivity of the $\mathrm{bSiO}_{2}$ (Van Bennekom et al., 1991). A partial explanation for the difference in the dissolution rate constant measured between diatomite and fresh $\mathrm{bSiO}_{2}$ could be a different $\mathrm{Al}$ content: The Si:Al ratio of the diatomite used in this study was 4.8 compared to the 2040 commonly found for fresh diatoms (Ragueneau et al., 2005). In our study, most of the amorphous silica from the diatomite stayed in its particulate phase, with the apparent 


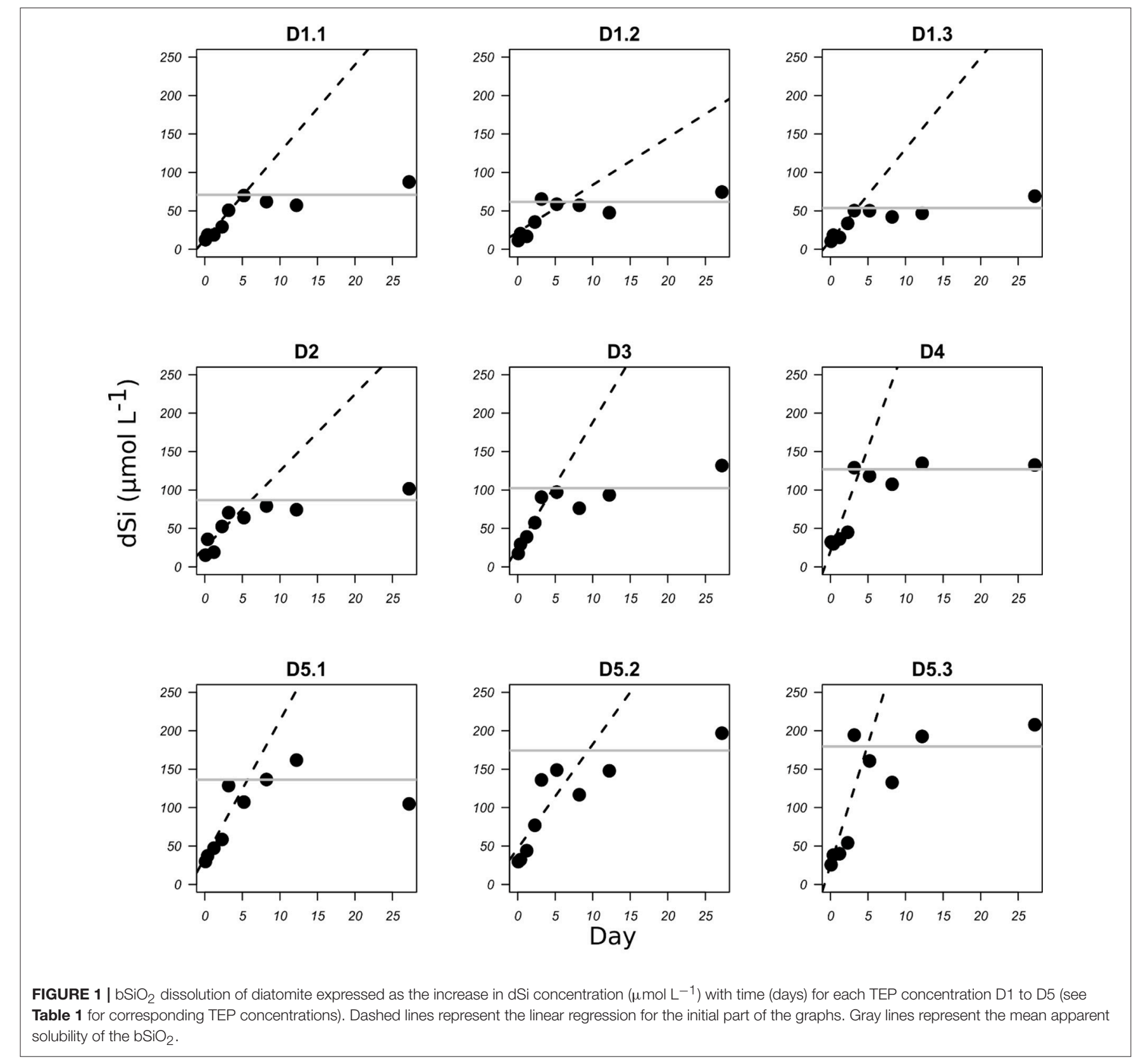

solubility of the $\mathrm{bSiO}_{2}$ going from 62 to $165 \mu \mathrm{mol} \mathrm{L} \mathrm{L}^{-1}$. By comparison, the solubility measured by Loucaides et al. (2008) for diatomite was $1,150 \mu \mathrm{M}$ at $25^{\circ} \mathrm{C}$ and a $\mathrm{pH}$ of 8. However, the diatomite used in his study contained a lot less $\mathrm{Al}$, and $\mathrm{Al}$ incorporation inside diatom frustules can also change solubility (Van Bennekom et al., 1991). An important result of our study is the correlation between the apparent solubility of the $\mathrm{bSiO}_{2}$ in the fossil diatoms batch and the TEP concentrations (Spearman correlation $=0.867^{* *}$, $p$-value $=0.002$ ). It has been suggested that $\mathrm{dSi}$ may adsorb on the TEP (Moriceau et al., 2014), which would explain the high dSi concentrations measured inside aggregates despite sometimes very low $\mathrm{dSi}$ concentrations in the surrounding seawater (Brzezinski et al., 1997). Our correlation between TEP concentrations and solubility of the $\mathrm{bSiO}_{2}$ tends to strengthen this hypothesis.

In our experiment, the influence of diatom byproducts on $\mathrm{bSiO}_{2}$ dissolution was monitored using the TEP concentrations because (1) diatoms generally produced EPS and TEP in larger quantities (Myklestad and Haug, 1972; Myklestad, 1974, 1995; Myklestad et al., 1989) and (2) previous experiments already showed an influence of polysaccharides on lithogenic $\mathrm{SiO}_{2}$ dissolution (Welch and Vandevivere, 1994). The $\mathrm{bSiO}_{2}$ specific dissolution rate constants of fossil diatoms were also correlated to TEP concentrations. As it was impossible to extract TEP from the rest of the diatom byproducts, and because the 

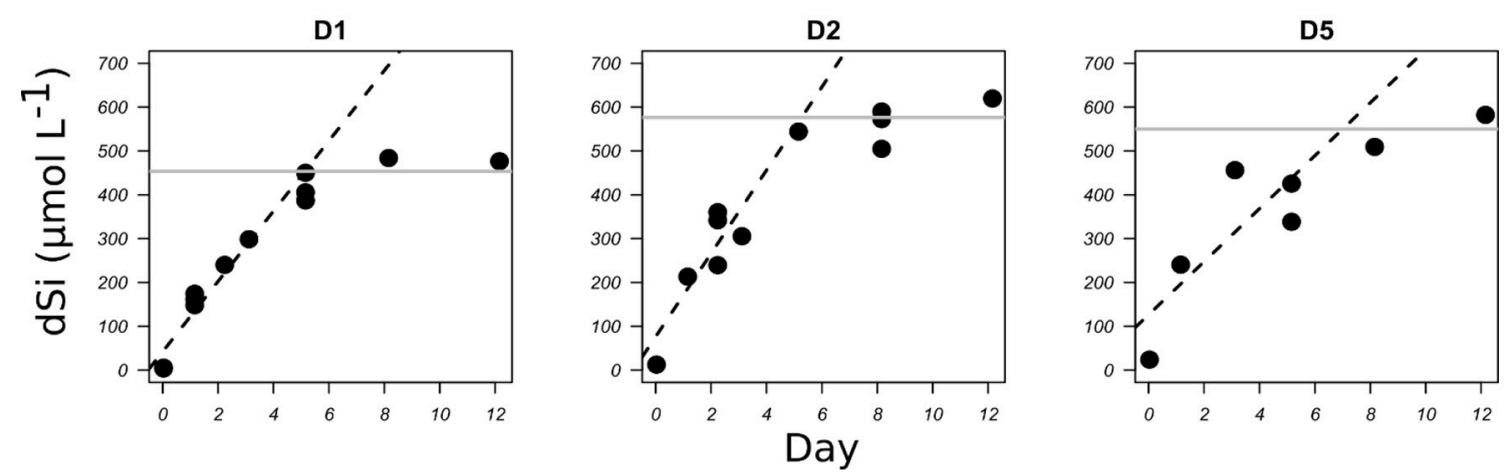

FIGURE 2 | bSiO 2 dissolution of freshly cleaned diatom frustules of $C$. muelleri expressed as the increase in dSi concentration $\left(\mu\right.$ mol $\mathrm{L}^{-1}$ ) with time (days) for three TEP concentrations (see Table 1). Dashed lines represent the linear regression for the initial part of the graphs. Gray lines represent the dSi concentrations at the plateau, in these cases the initial $\mathrm{bSiO}_{2}$ concentrations.

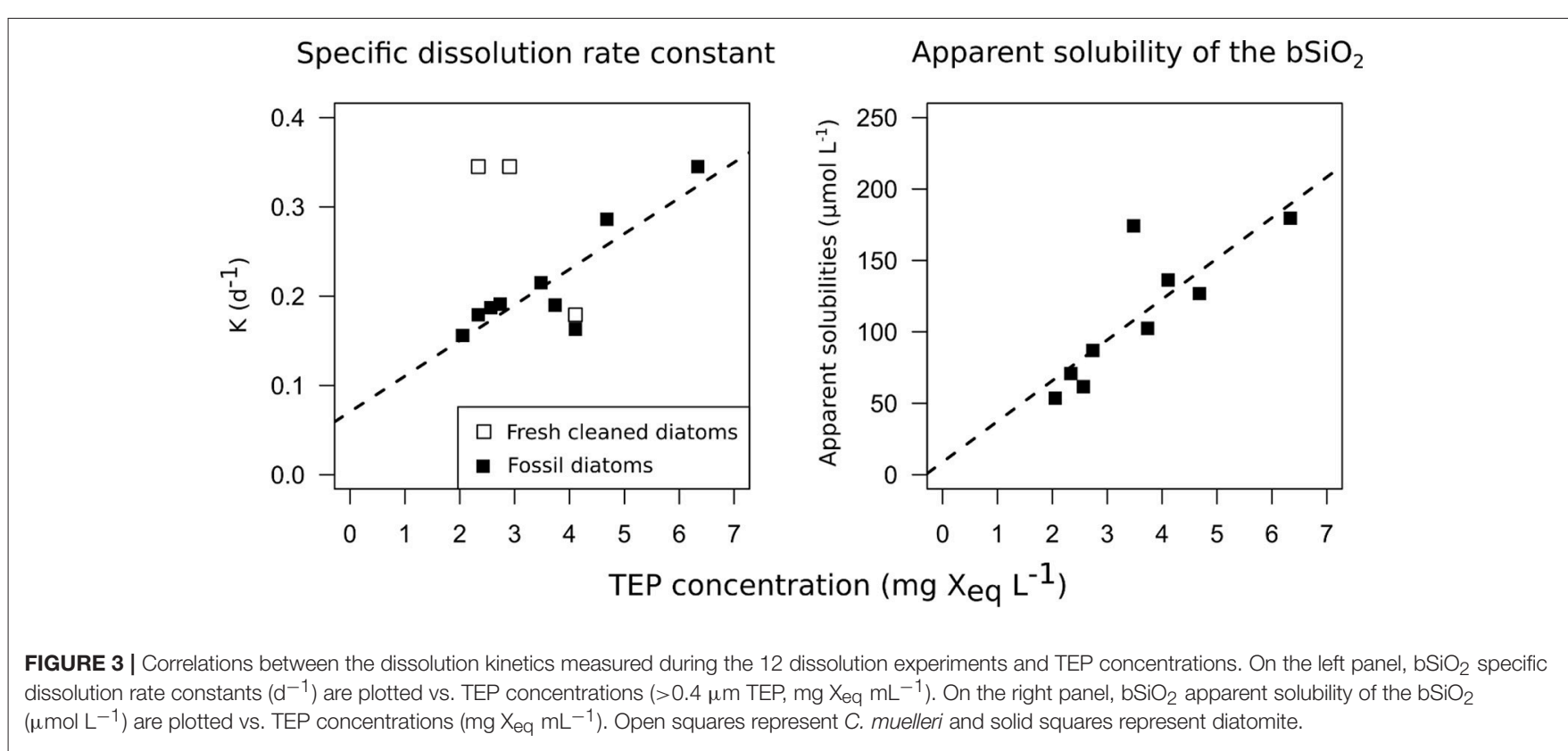

culture was not axenic, we must also have created a gradient of other molecules and bacteria concentration in the other dissolution batch. Analyses of diatom excretions at the end of a phytoplankton bloom or at the stationary phase in the culture showed considerable amounts of amino acids, proteoglycans, and extracellular polysaccharides containing residues of rhamnose, fucose, and galactose, with the carbohydrate contribution sometimes reaching $80-90 \%$ of the total extracellular release (Myklestad and Haug, 1972; Myklestad, 1974, 1995; Myklestad et al., 1989). Previous studies evidenced that fresh microbial EPS extracted from bacteria inhibit or promote the dissolution of $1 \mathrm{SiO}_{2}$ (Welch and Vandevivere, 1994; Ullman et al., 1996), and organic acids such as glucuronic acids favor $1 \mathrm{SiO}_{2}$ dissolution (Welch and Ullman, 1993, 1996; Vandevivere et al., 1994). However, the variation of the $\mathrm{bSiO}_{2}$ specific dissolution rate constants with the concentration of diatom byproducts could also be due to compounds other than polysaccharides, or to bacteria. To our knowledge no study has directly measured the potential influence of other byproducts such as amino acids. Concerning bacteria, proteolytic activities have little effect on $\mathrm{bSiO}_{2}$ dissolution, except for the removal of organic matter associated to the frustules occurring in the first days of the dissolution (Bidle and Azam, 2001). In our study we used frustules cleaned from their organic coating and indeed the dissolution of the $\mathrm{bSiO}_{2}$ from freshly cleaned diatoms was not increased by the bacteria gradient possibly resulting from our protocol. Roubeix et al. (2008) also hypothesized that bacterial colonization increases $\mathrm{bSiO}_{2}$ dissolution by creating a microenvironment with high ectoproteolytic activity at the diatom surface or by releasing organic compounds that can facilitate diatom $\mathrm{bSiO}_{2}$ dissolution (Roubeix et al., 2008). Rather, in their experiment they observed (1) no influence of bacterial 
activity and (2) a decrease of the dissolution rates when using cleaned frustules. Dissolution of the fossil $\mathrm{bSiO}_{2}$ was influenced by the gradient of diatom excretion/associated bacteria but had no influence or, possibly, an opposite effect on the $\mathrm{bSiO}_{2}$ dissolution of freshly cleaned frustules. If true, this would mean that diatoms or associated bacteria from the C. muelleri cultures are able to selectively increase the dissolution of $\mathrm{bSiO}_{2}$ from fossil diatoms but not the $\mathrm{bSiO}_{2}$ dissolution from the freshly cleaned diatoms.

More recently, other works from Akagi's team showed that by measuring rare earth elements on diatom frustules the dissolution of lithogenic silica in surface water could be an unexpected source of dSi for diatom growth (Akagi et al., 2011, 2014; Akagi, 2013a,b). Our experiment nicely complements their findings by adding a "how." Indeed, as it has been shown in a forest where mycorrhizal symbiosis with the roots of trees promotes the weathering of nutrients by releasing organic molecules (Griffiths et al., 1994), we can propose a similar hypothesis with diatoms. Bacteria associated to diatoms can selectively increase dissolution of silicate minerals (Vandevivere et al., 1994). Diatoms have acquired an ability to exudate specific organic molecules that can increase the dissolution of lithogenic silica and not their own biogenic silica. This strategy could be advantageous during silicate limitation episodes, whereby lithogenic silica becomes a source of silicon. This would be possible if diatoms produce organic ligands with a high affinity for $\mathrm{Al}$. Removal of $\mathrm{Al}$ in preference to $\mathrm{Si}$ in $\mathrm{Al}$ enriched silica would increase lithogenic silica and fossil $\mathrm{bSiO}_{2}$ dissolution without weakening their own frustule.

\section{CONCLUSION}

The main goal of this study was to understand the influence of TEP on biogenic silica dissolution. We used two different

\section{REFERENCES}

Akagi, T. (2013a). Rare earth element (REE)-silicic acid complexes in seawater to explain the incorporation of REEs in opal and the "leftover" REEs in surface water: new interpretation of dissolved REE distribution profiles. Geochim. Cosmochim. Acta 113, 174-192. doi: 10.1016/j.gca.2013.03.014

Akagi, T. (2013b). Revision of the dissolution kinetics of aggregated settling particles. Mem. Fac. Sci. Kyushu Univ. Ser. Earth Planet Sci. 33, 1-5. Available online at: http://hdl.handle.net/2324/1397628

Akagi, T., Fu, F., Hongo, Y., and Takahashi, K. (2011). Composition of rare earth elements in settling particles collected in the highly productive North Pacific Ocean and Bering Sea: implications for siliceous-matter dissolution kinetics and formation of two REE-enriched phases. Geochim. Cosmochim. Acta 75, 4857-4876. doi: 10.1016/j.gca.2011.06.001

Akagi, T., Yasuda, S., Asahara, Y., Emoto, M., and Takahashi, K. (2014). Diatoms spread a high epsilon Nd-signature in the North Pacific Ocean. Geochem. J. 48, 121-131. doi: 10.2343/geochemj.2.0292

Aminot, A., and Kérouel, R. (2007). Dosage Automatique des Nutriments Dans les Eaux Marines: Méthodes en Flux Continu, ed Quae (Plouzané: Ifremer).

Bidle, K. D., and Azam, F. (2001). Bacterial control of silicon regeneration from diatom detritus: significance of bacterial ectohydrolases and species identity. Limnol. Oceanogr. 46, 1606-1623. doi: 10.4319/lo.2001.46.7.1606

Boutorh, J., Moriceau, B., Gallinari, M., Ragueneau, O., and Bucciarelli, E. (2016). Effect of trace metal-limited growth on the postmortem dissolution of the types of $\mathrm{bSiO}_{2}$ : fossil diatoms (diatomite) and cleaned frustules of cultured diatoms (C. muelleri). Our results evidenced a correlation between TEP concentrations and $\mathrm{bSiO}_{2}$ dissolution rate constants and solubility of the $\mathrm{bSiO}_{2}$ for fossil diatoms, however diatom excretions had no influence on $\mathrm{bSiO}_{2}$ dissolution from freshly cleaned frustules, except for possible protection at the highest TEP concentration.

In the light of the results obtained here, diatom byproducts seem to favor Al-enriched silica dissolution, such as bacterial EPS do for feldspars and aluminosilicates (Welch and Ullman, 1993, 1996; Vandevivere et al., 1994) as compared to fresh $\mathrm{bSiO}_{2}$. In case of limitations, TEP are produced in greater quantities by diatoms that may provide them with an unexpected source of nutrients through the increase of weathering. This would explain the Rare Earth concentrations sometimes measured on diatom frustules and confirm the theory that diatoms may directly uptake silica on lithogenic particles.

\section{AUTHOR CONTRIBUTIONS}

JT writing paper, laboratory experiment, sample analysis, data treatment; BM writing paper, support in lab experiment, supervisor.

\section{ACKNOWLEDGMENTS}

We would like to thank the Argenton Ifremer experiment station for providing us the algae. We thank Jill Naomi Sutton for her help in editing the English language manuscript, Lucie Blondel for the ICP-AES analysis of diatomite, and everyone else in LEMAR for assistance during the experiment. This work was partly supported by the ANR BIOPSIS project, grant ANR-16CE01-0002-01 of the French Agence Nationale de la Recherche, and by the CHIBIDO team of the LEMAR. marine diatom Pseudo-nitzschia delicatissima. Glob. Biogeochem. Cycles 30, 57-69. doi: 10.1002/2015GB005088

Boyle, E. (1998). Oceanography pumping iron makes thinner diatoms. Nature 393, 733-734. doi: 10.1038/31585

Brzezinski, M. A., Baines, S. B., Balch, W. M., Beucher, C. P., Chai, F., Dugdale, R. C., et al. (2011). Co-limitation of diatoms by iron and silicic acid in the equatorial Pacific. Deep Sea Res. Part II Top. Stud. Oceanogr. 58, 493-511. doi: 10.1016/j.dsr2.2010.08.005

Brzezinski, M. A., Phillips, D. R., Chavez, F. P., Friederich, G. E., and Dugdale, R. C. (1997). Silica production in the Monterey, California, upwelling system. Limnol. Oceanogr. 42, 1694-1705. doi: 10.4319/lo.1997.42.8.1694

Claquin, P., Probert, I., Lefebvre, S., and Veron, B. (2008). Effects of temperature on photosynthetic parameters and TEP production in eight species of marine microalgae. Aquat. Microb. Ecol. 51, 1-11. doi: 10.3354/ame 01187

Dixit, S., and Van Cappellen, P. (2003). Predicting benthic fluxes of silicic acid from deep-sea sediments. J. Geophys. Res. Oceans 108:3334. doi: 10.1029/2002JC001309

Eyring, H. (1936). Viscosity, plasticity, and diffusion as examples of absolute reaction rates. J. Chem. Phys. 4, 283-291. doi: 10.1063/1.1749836

Garvey, M., Moriceau, B., and Passow, U. (2007). Applicability of the FDA assay to determine the viability of marine phytoplankton under different environmental conditions. Mar. Ecol. Prog. Ser. 352, 17-26. doi: 10.3354/ meps07134 
Greenwood, J. E., Truesdale, V. W., and Rendell, A. R. (2001). Biogenic silica dissolution in seawater-in vitro chemical kinetics. Prog. Oceanogr. 48, 1-23. doi: 10.1016/S0079-6611(00)00046-X

Griffiths, R. P., Baham, J. E., and Caldwell, B. A. (1994). Soil solution chemistry of ectomycorrhizal mats in forest soil. Soil Biol. Biochem. 26, 331-337. doi: 10.1016/0038-0717(94)90282-8

Irigoien, X., Harris, R. P., Verheye, H. M., Joly, P., Runge, J., Starr, M., et al. (2002). Copepod hatching success in marine ecosystems with high diatom concentrations. Nature 419, 387-389. doi: 10.1038/nature01055

Jin, X., Gruber, N., Dunne, J. P., Sarmiento, J. L., and Armstrong, R. A. (2006). Diagnosing the contribution of phytoplankton functional groups to the production and export of particulate organic carbon, $\mathrm{CaCO} 2$, and opal from global nutrient and alkalinity distributions: diagnosing phytoplankton functional groups. Glob. Biogeochem. Cycles 20:GB201. doi: 10.1029/2005GB002532

Kamatani, A., and Riley, J. P. (1979). Rate of dissolution of diatom silica walls in seawater. Mar. Biol. 55, 29-35. doi: 10.1007/BF00391714

Lasbleiz, M., Leblanc, K., Blain, S., Ras, J., Cornet-Barthaux, V., Hélias Nunige, S., et al. (2014). Pigments, elemental composition (C, N, P, and $\mathrm{Si}$ ), and stoichiometry of particulate matter in the naturally iron fertilized region of Kerguelen in the Southern Ocean. Biogeosciences 11, 5931-5955. doi: 10.5194/bg-11-5931-2014

Loucaides, S., Cappellen, P. V., and Behrends, T. (2008). Dissolution of biogenic silica from land to ocean: role of salinity and pH. Limnol. Oceanogr. 53, 1614-1621. doi: 10.4319/lo.2008.53.4.1614

Loucaides, S., Van Cappellen, P., Roubeix, V., Moriceau, B., and Ragueneau, O. (2012). Controls on the recycling and preservation of biogenic silica from biomineralization to burial. Silicon 4, 7-22. doi: 10.1007/s12633-0119092-9

Mari, X., and Burd, A. (1998). Seasonal size spectra of transparent exopolymeric particles (TEP) in a coastal sea and comparison with those predicted using coagulation theory. Mar. Ecol. Prog. Ser. 163, 63-76. doi: 10.3354/meps163063

Mari, X., and Kiørboe, T. (1996). Abundance, size distribution and bacterial colonization of transparent exopolymeric particles (TEP) during spring in the Kattegat. J. Plankton Res. 18, 969-986. doi: 10.1093/plankt/18.6.969

Mari, X., Passow, U., Migon, C., Burd, A. B., and Legendre, L. (2017). Transparent exopolymer particles: effects on carbon cycling in the ocean. Prog. Oceanogr. 151, 13-37. doi: 10.1016/j.pocean.2016.11.002

Moriceau, B., Gallinari, M., Soetaert, K., and Ragueneau, O. (2007b). Importance of particle formation to reconstructed water column biogenic silica fluxes. Glob. Biogeochem. Cycles 21:GB3012. doi: 10.1029/2006GB002814

Moriceau, B., Garvey, M., Ragueneau, O., and Passow, U. (2007a). Evidence for reduced biogenic silica dissolution rates in diatom aggregates. Mar. Ecol. Prog. Ser. 333, 129-142. doi: 10.3354/meps333129

Moriceau, B., Laruelle, G., Passow, U., Van Cappellen, P., and Ragueneau, O. (2014). Biogenic silica dissolution in diatom aggregates: insights from reactive transport modelling. Mar. Ecol. Prog. Ser. 517, 35-49. doi: 10.3354/meps 11028

Myklestad, S. (1974). Production of carbohydrates by marine planktonic diatoms. I. Comparison of nine different species in culture. J. Exp. Mar. Biol. Ecol. 15, 261-274. doi: 10.1016/0022-0981(74)90049-5

Myklestad, S., and Haug, A. (1972). Production of carbohydrates by the marine diatom Chaetoceros affinis var. willei (Gran) Hustedt. I. Effect of the concentration of nutrients in the culture medium. J. Exp. Mar. Biol. Ecol. 9, 125-136. doi: 10.1016/0022-0981(72)90041-X

Myklestad, S., Holm-Hansen, O., Vårum, K. M., and Volcani, B. E. (1989). Rate of release of extracellular amino acids and carbohydrates from the marine diatom Chaetoceros affinis. J. Plankton Res. 11, 763-773. doi: 10.1093/plankt/11.4.763

Myklestad, S. M. (1995). Release of extracellular products by phytoplankton with special emphasis on polysaccharides. Sci. Total Environ. 165, 155-164. doi: 10.1016/0048-9697(95)04549-G

Nelson, D. M., and Goering, J. J. (1977). Near-surface silica dissolution in the upwelling region off northwest Africa. Deep Sea Res. 24, 65-73.

Nelson, D. M., Goering, J. J., and Boisseau, D. W. (1981). "Consumption and regeneration of silicic acid in three coastal upwelling systems," in Coastal Upwelling, ed F. A. Richards (Washington, DC: American Geophysical Union), 242-256.

Nelson, D. M., Tréguer, P., Brzezinski, M. A., Leynaert, A., and Quéguiner, B. (1995). Production and dissolution of biogenic silica in the ocean: revised global estimates, comparison with regional data and relationship to biogenic sedimentation. Glob. Biogeochem. Cycles 9, 359-372. doi: 10.1029/95GB01070

Passow, U. (2002a). Production of transparent exopolymer particles (TEP) by phyto- and bacterioplankton. Mar. Ecol. Prog. Ser. 236, 1-12. doi: 10.3354/meps236001

Passow, U. (2002b). Transparent exopolymer particles (TEP) in aquatic environments. Prog. Oceanogr. 55, 287-333. doi: 10.1016/S0079-6611 (02)00138-6

Passow, U., and Alldredge, A. L. (1995). A dye-binding assay for the spectrophotometric measurement of transparent exopolymer particles (TEP). Limnol. Oceanogr. 40, 1326-1335. doi: 10.4319/lo.1995.40.7.1326

Passow, U., Engel, A., and Ploug, H. (2003). The role of aggregation for the dissolution of diatom frustules. FEMS Microbiol. Ecol. 46, 247-255. doi: 10.1016/S0168-6496(03)00199-5

Pondaven, P., Gallinari, M., Chollet, S., Bucciarelli, E., Sarthou, G., Schultes, S., et al. (2007). Grazing-induced changes in cell wall silicification in a marine diatom. Protist 158, 21-28. doi: 10.1016/j.protis.2006.09.002

Ragueneau, O., Savoye, N., Del Amo, Y., Cotten, J., Tardiveau, B., and Leynaert, A. (2005). A new method for the measurement of biogenic silica in suspended matter of coastal waters: using Si:Al ratios to correct for the mineral interference. Cont. Shelf Res. 25, 697-710. doi: 10.1016/j.csr.2004. 09.017

Roubeix, V., Becquevort, S., and Lancelot, C. (2008). Influence of bacteria and salinity on diatom biogenic silica dissolution in estuarine systems. Biogeochemistry 88, 47-62. doi: 10.1007/s10533-008-9193-8

Rousseaux, C., and Gregg, W. (2013). Interannual variation in phytoplankton primary production at a global scale. Remote Sens. 6, 1-19. doi: 10.3390/rs6010001

Sanders, R., Henson, S. A., Koski, M., De La Rocha, C. L., Painter, S. C., Poulton, A. J., et al. (2014). The biological carbon pump in the North Atlantic. Prog. Oceanogr. 129, 200-218. doi: 10.1016/j.pocean.2014.05.005

Seuront, L. (2006). Effect of salinity on the swimming behaviour of the estuarine calanoid copepod Eurytemora affinis. J. Plankton Res. 28, 805-813. doi: 10.1093/plankt/fbl012

Smetacek, V. (1999). Diatoms and the ocean carbon cycle. Protist 150, 25-32. doi: 10.1016/S1434-4610(99)70006-4

Suroy, M., Moriceau, B., Boutorh, J., and Goutx, M. (2014). Fatty acids associated with the frustules of diatoms and their fate during degradation:a case study in Thalassiosira weissflogii. Deep Sea Res. Part I Oceanogr. Res. Pap. 86, 21-31. doi: 10.1016/j.dsr.2014.01.001

Suroy, M., Panagiotopoulos, C., Boutorh, J., Goutx, M., and Moriceau, B. (2015). Degradation of diatom carbohydrates: a case study with N- and Si-stressed Thalassiosira weissflogii. J. Exp. Mar. Biol. Ecol. 470, 1-11. doi: 10.1016/j.jembe.2015.04.018

Takeda, S. (1998). Influence of iron availability on nutrient consumption ratio of diatoms in oceanic waters. Nature 393, 774-777. doi: 10.1038/31674

Thornton, D. C. O. (2014). Dissolved organic matter (DOM) release by phytoplankton in the contemporary and future ocean. Eur. J. Phycol. 49, 20-46. doi: 10.1080/09670262.2013.875596

Tréguer, P., and Le Corre, P. (1975). Manuel d'Analyse des sels Nutritifs dans l'eau de Mer (Utilisation de l'autoAnalyseur II), Université de Bretagne Occidentale, 2nd Edn. Laboratoire d'Océanographie Chimique, Université de Bretagne Occidentale, Brest.

Tréguer, P. J., and De La Rocha, C. (2013). The world ocean silica cycle. Annu. Rev. Mar. Sci. 5, 477-501. doi: 10.1146/annurev-marine-121211-172346

Tréguer, P., Nelson, D. M., Van Bennekom, A. J., DeMaster, D. J., Leynaert, A., and Queguiner, B. (1995). The silica balance in the world ocean: a reestimate. Science 268, 375-379. doi: 10.1126/science.268.5209.375

Truesdale, V. W., Greenwood, J. E., and Rendell, A. (2005). The rate-equation for biogenic silica dissolution in seawater - new hypotheses. Aquat. Geochem. 11, 319-343. doi: 10.1007/s10498-004-7921-9

Ullman, W. J., Kirchman, D. L., Welch, S. A., and Vandevivere, P. (1996). Laboratory evidence for microbially mediated silicate mineral dissolution in nature. Chem. Geol. 132, 11-17. doi: 10.1016/S0009-2541(96)00036-8

Van Bennekom, A. J., Buma, A. G. J., and Nolting, R. F. (1991). Dissolved aluminium in the Weddell-Scotia Confluence and effect of $\mathrm{Al}$ on the dissolution kinetics of biogenic silica. Mar. Chem. 35, 423-434. doi: 10.1016/S0304-4203(09)90034-2 
Van Cappellen, P., Dixit, S., and van Beusekom, J. (2002). Biogenic silica dissolution in the oceans: reconciling experimental and field-based dissolution rates. Glob. Biogeochem. Cycles 16, 23-1-23-10. doi: 10.1029/2001GB001431

Vandevivere, P., Welch, S. A., Ullman, W. J., and Kirchman, D. L. (1994). Enhanced dissolution of silicate minerals by bacteria at near-neutral pH. Microb. Ecol. 27, 241-251. doi: 10.1007/BF00182408

Welch, S. A., and Ullman, W. J. (1993). The effect of organic acids on plagioclase dissolution rates and stoichiometry. Geochim. Cosmochim. Acta 57, 2725-2736. doi: 10.1016/0016-7037(93)90386-B

Welch, S. A., and Ullman, W. J. (1996). Feldspar dissolution in acidic and organic solutions: compositional and $\mathrm{pH}$ dependence of dissolution rate. Geochim. Cosmochim. Acta 60, 2939-2948. doi: 10.1016/0016-7037(96)00134-2

Welch, S. A., and Vandevivere, P. (1994). Effect of microbial and other naturally occurring polymers on mineral dissolution. Geomicrobiol. J. 12, 227-238. doi: 10.1080/01490459409377991
Wotton, R. S. (2004). The ubiquity and many roles of exopymers in aquatic systems. Sci. Mar. 68, 13-21. doi: 10.3989/scimar.2004.68s113

Conflict of Interest Statement: The authors declare that the research was conducted in the absence of any commercial or financial relationships that could be construed as a potential conflict of interest.

The reviewer HO and handling Editor declared their shared affiliation.

Copyright (c) 2018 Toullec and Moriceau. This is an open-access article distributed under the terms of the Creative Commons Attribution License (CC BY). The use, distribution or reproduction in other forums is permitted, provided the original author(s) and the copyright owner are credited and that the original publication in this journal is cited, in accordance with accepted academic practice. No use, distribution or reproduction is permitted which does not comply with these terms. 